Article

\title{
Arrival or Transient Spaces? Differentiated Politics of Mobilities, Socio-Technological Orderings and Migrants' Socio-Spatial Embeddedness
}

\author{
Tabea Bork-Hüffer and Simon Alexander Peth * \\ Department of Geography, University of Innsbruck, 6020 Innsbruck, Austria; \\ E-Mails: tabea.bork-hueffer@uibk.ac.at (T.B.H.), simon.peth@uibk.ac.at (S.A.P.) \\ * Corresponding author
}

Submitted: 8 March 2020 | Accepted: 29 May 2020 | Published: 28 July 2020

\begin{abstract}
For the last decade there has been a lively debate on urban arrival spaces. Saunders' (2011) widely received book Arrival Cities can be seen as catalyst of this debate. Taking a hitherto largely unexplored comparative approach, based on two empirical research studies on migrant workers and highly-skilled migrants in Singapore, this study debates the notion of arrival cities and spaces and argues for a differentiated perspective on the complex and interdependent processes of spatially and socially arriving. By comparing how the politics of mobilities, migration management and differential inclusion influence the migration trajectories of workers and professionals we argue that the concept of transient spaces might be a more fruitful approach for understanding the differentiated processes of arriving and (not) becoming socio-spatially embedded. In order to educe the relevance of a processual perspective, and for a systematic comparison, we apply four analytical dimensions that shed light on the process of migrating, arriving, and passing through. These four dimensions comprise (1) arriving, (2) settling, (3) mingling locally and translocally, and (4) planning ahead for future mobilities. We argue that the scholarship on politics of mobilities needs to take note of the combined effects of states' and companies' neoliberal politics of mobility throughout the migration process, and of the increasing relevance of socio-technological orderings, which imprint migrants' socio-spatial embedding.
\end{abstract}

\section{Keywords}

arrival city; comparative approach; migration management; Singapore; translocal spaces

Issue

This article is part of the issue "Urban Arrival Spaces: Social Co-Existence in Times of Changing Mobilities and Local Diversity" edited by Yvonne Franz (University of Vienna, Austria) and Heike Hanhörster (ILS-Research Institute for Regional and Urban Development, Germany).

(C) 2020 by the authors; licensee Cogitatio (Lisbon, Portugal). This article is licensed under a Creative Commons Attribution 4.0 International License (CC BY).

\section{Introduction}

For the last decade, the debate on urban arrival spaces has been in full swing. Saunders' (2011) widely received book Arrival Cities can be seen as a catalyst of this debate. In contrast to previous contributions, Saunders offers a positive narrative on arrival cities. The arrival city "is not a temporary anomaly" but has become the global norm (Saunders, 2011, p. 35). Saunders exemplifies this by pointing to a myriad of arrival cities/neighborhoods such as the Kiez Kreuzberg in Berlin, banlieues in Paris, favelas in São Paulo, slums in Mumbai, barrios in Los Angeles, and entire cities such as Hong Kong, Dubai, and Singapore. As Massey (2005) prominently highlighted, however, we have to be aware of the specificities of spaces, which "are a product of interrelationsconnections and disconnections" (Massey, 2005, p. 67). They are shaped not only by diverging historicities, culture, and geographic settings, but also by divergent politics of mobility (Massey, 1991, p. 26), eventually resulting in migrant subjects' 'differential inclusion' (Ye, 2017).

We contribute to this debate by adopting a processual and differentiated perspective on the dynamics of arriving and (not) becoming socio-spatially embedded 
by two migrant populations in Singapore: migrant workers and professionals. We ask: How do they experience their arrival, and the following process of (not) becoming socio-spatially embedded in Singapore, to planning ahead for future mobility or stay? What are reasons for the differences in their socio-spatial embeddedness?

Singapore's migration management positions migrants very differently in the city-state's assemblage, based on their skills, origins, and gender. Whereas there is rich research on different migrant groups in Singapore, there is a lack of comparative studies. Based on empirical research by both authors with qualitative multi-method approaches we offer a comparative approach. The results of this study inform the notion of arrival spaces and argue for a differentiated perspective on the complex and interdependent processes of arriving spatially and socially, which considers the relationality, translocality and technological co-production of such spaces that we frame with Bork-Hüffer et al. (2016) as 'transient urban spaces.' We reveal how the politics of mobilities, socio-technological orderings, migration management and differential inclusion, as well as migrants' reflexive responses and their translocal connectivity, affect workers' and professionals' spatial and social embeddedness in transient spaces differently throughout the phases of their migration pathways. We do so by reflecting upon and comparing four analytic and processual dimensions that we developed inductively out of an empirical comparison of our case studies. This allows us to distinguish how the dynamic interplay of these factors influences migrants' experiences of arrival (dimension 1: arriving), (not) becoming spatially and emotionally embedded (dimension 2: settling), local and translocal interactions (dimension 3: mingling and connecting), and their perspectives, plans, and strategies of staying or moving again (dimension 4: planning ahead).

\section{Arrival and/or Transient Spaces: Balancing Politics, Relationality, Moorings, and Frictions in Theorizations of Migration Processes to and through Cities}

Saunders' understanding of arrival spaces as fragments within the urban fabric - such as neighborhoods - which are characterized by high immigration flows and diversity (Saunders, 2011, p. 15) is not new. It can be traced back to the 1930s and the Chicago School of Social Ecology's contributions on urban transit zones and ethnic neighbourhoods (Meeus, Arnaut, \& van Heur, 2019). These posited that arrival spaces cannot be defined merely by physical structures, but also by people, practices, and social structures. Other contributions on 'migrant settlements' (Abu-Lughod, 1961), 'migrant neighborhoods' (Conzen, 1979; Solis, 1971), the 'immigrant metropolis' (Nee, Sanders, \& Sernau, 1994), 'immigrant enclaves' (Marcuse, 1996; Wilson \& Portes, 1980), 'ethnic minority neighbourhoods' (Logan, 2006), or 'shadow cities' (Neuwirth, 2005) followed. Most authors describe these urban arrival spaces as multicultural, diverse, and com- plex fragments within an urban assemblage and as "hybrid living spaces' (Moore, 2015). They are delimited from other urban spaces which have experienced far fewer inflows of people, ideas, goods, social practices, identities, etc. (Meeus et al., 2019).

Still, amendments were developed in response to particularly Saunder's conception. Amin (2013), for example, questioned the limitation of arrival spaces to specific urban fragments, leading to a "telescopic urbanism" (Amin, 2013, p. 484) and an overemphasis of locational scales such as the neighborhood. Similarly, Smith (2005) argued that associating migrants in the city with specific locations is misleading since they navigate through and within the city. As migrants venture through the city, social encounters and social coexistence take place not only at a specific locale but also through space and time (Massey, 2005). Another aspect that has less been addressed in the arrival spaces literature is the complex relationality of people and places through translocal connections elsewhere (Bork-Hüffer et al., 2016; Peth, Sterly, \& Sakdapolrak, 2018; Steinbrink, 2009).

Picking up the (trans)local relationality of space in the context of migrant mobility, Bork-Hüffer et al. (2016, p. 142) developed the notion of 'transient urban spaces' as "diverse types of overlapping social and material spaces in cities that are (re)produced and transformed by people's everyday practices and their local and translocal interactions" (Bork-Hüffer et al., 2016, p. 142). Trasient spaces encompass:

Spaces of face-to-face interaction, virtual, and other ways of contact, and [they] can serve an endless number of functions, for example, as space of communication, housing, business, meeting, or recreation but also as space of domination, surveillance, of closure or openness, public, or private space. (Bork-Hüffer et al., 2016, p. 135)

These earlier conceptions of transient spaces must be amended by an acknowledgment of the increasing sociotechnological co-production of spaces in the 'digitally mediated city' (Rose, 2017) through codes, sensors, algorithms, and the affordances and agencies of digital technologies (Kitchin, 2017). The ambivalent role these take, often deepening the "exclusion, adverse incorporation, impoverishment and enrichment" (Elwood, 2020, p. 1) of diverse urban subjects, has been emphasized by postcolonial, (post)feminist and posthuman scholars (Datta, 2018; Gabrys, 2014; Rose, 2017).

Whereas the notion of arrival conjures a sense of a relatively brief timespan, the transient spaces concept emphasizes the emergent and dynamic nature of space and the importance of understanding migration processes in the context of socio-political and sociotechnological historicities as much as individual trajectories, altogether influencing the (aspired) embeddedness of migrants in urban societies. Criticism has also highlighted that 'arrival' implies a notion of a pathway 
towards social integration, social upwards mobility, and permanent stay (Amin, 2013; Meeus et al., 2019). Yet both migrants' aspirations to stay on the one hand, and the realities of their stays on the other "may vary from permanent to temporal to circular forms" (Bork-Hüffer et al., 2016, p. 134). Hereby, case studies have shown that the interplay of migration and urbanization often produces precarious living conditions and protracted insecurity (Peth et al., 2018; Porst \& Sakdapolrak, 2018; Swider, 2015), which may force people into a situation of 'permanent temporariness' (Swider, 2015; Yiftachel, 2009). Koh (2015) has argued that due to shifting periods and understandings of citizenship legislation and shifts in individual migrants' life courses, even citizenship is characterized by temporalities and fluidities.

Then again, fixities and structural moorings must not be neglected-they are often as important as movements themselves (Hannam, Sheller, \& Urry, 2006). Bork-Hüffer et al. (2016) argue that we have to take note of different degrees of everyday (trans)local (im-)mobilities of migrants. These (im-)mobilities are shaped by politics of space, mobilities and technologies on the one hand and migrants' reflexive making of spaces and mobilities on the other (Glick Schiller \& Çağlar, 2016; Oswin \& Yeoh, 2010). The politics of space and mobilities comprise official rules and regulations, practiced politics, and the public discourse-ranging from 'hostile environments' (Hiam, Steele, \& McKee, 2018) to 'sanctuary cities' (Bagelman, 2016). They strongly influence the drivers, velocities, rhythms, routes, experiences, frictions, and fixities of mobilities (Cresswell, 2010). As Massey (1991, pp. 25-26) noted:

Different social groups and different individuals, are placed in very distinct ways in relation to these flows and interconnections....Some people are more in charge of it than others; some initiate flows and movement, others don't; some are more on the receiving-end of it than others; some are effectively imprisoned by it.

Pécoud (2013, p. 2) argued that countries increasingly pursue entrepreneurial approaches to migration governance that often seek "the transformation of a complex, multifaceted, sometimes unlawful and always challenging process into 'predictable,' 'sound,' 'manageable,' 'orderly' and rule-obeying dynamics." As we will argue, the role of (transnational) companies in the neoliberal co-managing and streamlining of migrant subjects' mobilities in this process must be recognized. Still, authorities' and companies' endeavors are negotiated, followed, ignored, or avoided by migrants through their tactical quotidian practices (Bork-Hüffer et al., 2016; Papadopoulos \& Tsianos, 2013). Adding an important dimension, Ye (2017) discussed how migrants' incorporation process is not only shaped by state regulation but also through social norms and civility in the politics of everyday co-existence. She emphasized how "the nor- mative and productive categorisations of race, citizenship and civility in shared spaces" become (re-)produced through both of these sets of factors, leading to a 'differential inclusion' (Ye, 2017, p. 1033) of migrant subjects in the city.

\section{Migration Management and the Bifurcation of Migrant Labor in Singapore}

Compared to many other migrant-receiving cities, which have witnessed at least partly a momentum of uncontrolled urban transformation, Singapore has enacted a very strict political control and management of migration and urban development (Platt, Baey, Yeoh, Khoo, \& Lam, 2017; Wong, 1997) as part of an overall stateengineered endeavor seeking "world recognition" (Ong, 2011, p. 5) and branding Singapore as world-class city. Singapore has established one of the most sophisticated and strict migration-management systems worldwide (cf. Peth et al., 2018), which simultaneously produced a bifurcated migration system (Yeoh, 2006) strongly separating and differentiating migrant subjects according to qualification and skills, origins, and gender.

Starting from the 1980s, highly-skilled migrants, socalled 'foreign talents,' largely working in the services sector, were regarded as key to the country's pan-Asian and global economic competitiveness and the city's international and cosmopolitan image (Beaverstock, 2011; Ho, 2006; Iwasaki, 2015; Yeoh, 2006). Whereas these professionals enjoy wide-ranging freedoms, 'lower-skilled' migrant workers are confronted with various restrictions (see Figure 1). Their inflow is managed through quota systems based on nationality and economic sector; they are not allowed to choose their accommodation freely, and may not marry or have children in Singapore (Peth et al., 2018). Migrant workers' occupational fields are gendered: women are recruited as domestic or servicesector workers, while men are employed in the construction, manufacturing, and marine sectors.

Despite the government's initial plans to render the country's reliance on low-skilled workers unnecessary, they still make up the largest share of the 1.7 million so-called non-residents or temporary residents (out of a total population of 5.7 million people, Department of Statistics Singapore, 2019a). Together with 520,000 permanent residents (Department of Statistics Singapore, 2019a), temporary and permanent residents make up $37.1 \%$ of the total population and $43 \%$ of the current work force (the latter number includes daily commuters from Malaysia; Department of Statistics Singapore, 2019b). Singaporeans' increased dissatisfaction with immigration, and the growing population, particularly since the global economic crisis of 2008-2009, made the government react with measures that became known as 'Singaporeans First' policies, which increasingly affect the stay and in-migration of migrants (Bork-Hüffer, 2017; Gomes, 2017; Yeoh \& Lam, 2016; see also Section 5). Although Singapore is truly a mobile city and migration 


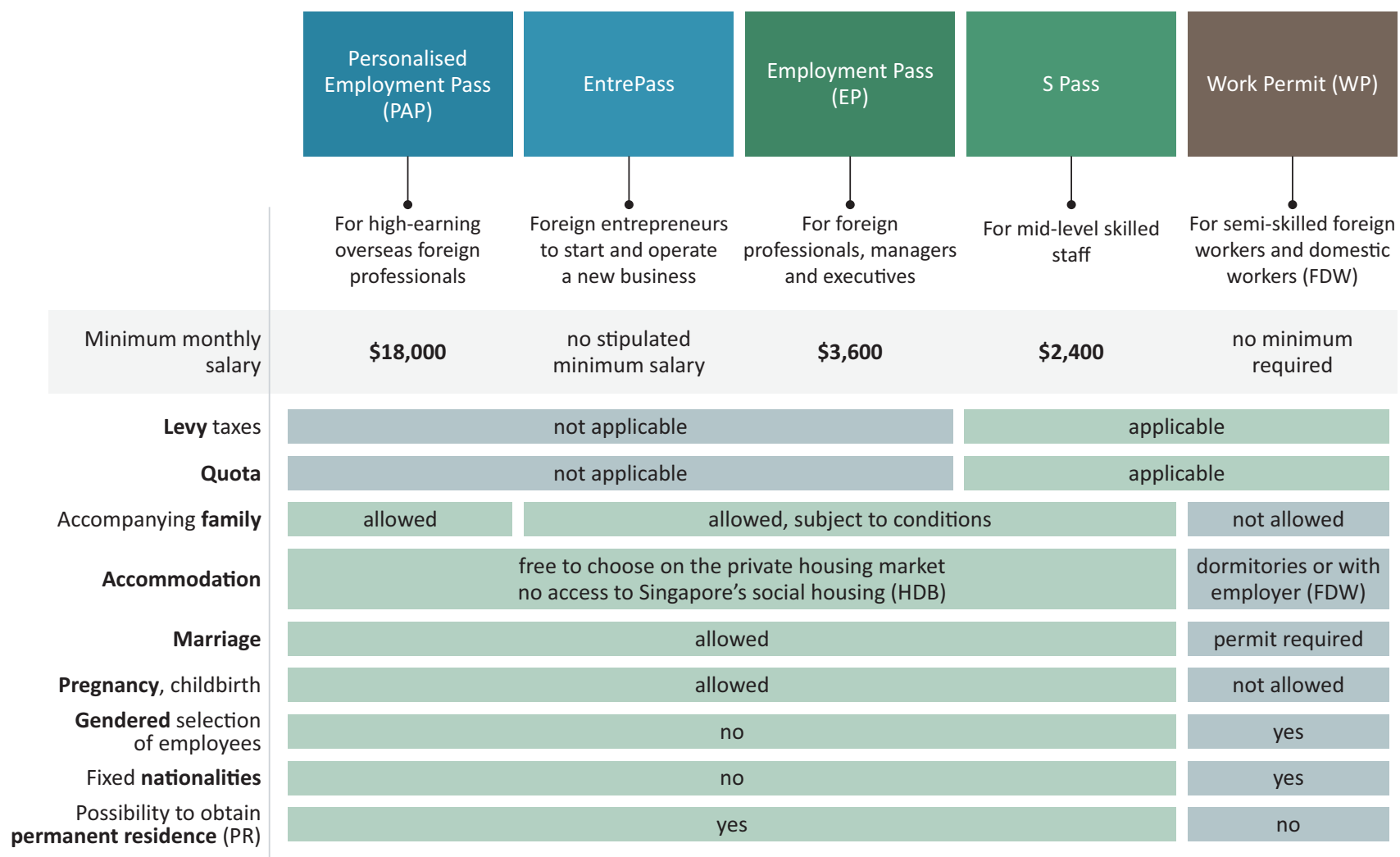

Figure 1. The main types of work passes and related freedoms in Singapore. Source: Own draft, based on Iwasaki (2015) and Ministry of Manpower of Singapore (2020).

has become part of everyday life, migrant mobilities are highly differential and selective (Ye, 2017).

\section{Methodology}

This article is based on research by both authors, each using multi-method approaches and incorporating indepth interviews, photo elicitation, mobile media elicitation, and cognitive and migration pathway mappings. The first author focused on migrant professionals whose fields of work reflected the above-named employment fields (Section 3) for professionals in Singapore. The second author focused on Thai migrant workers, who were working on construction sites and in shipyards in Singapore.

The research with Thai workers in Singapore was integrated into a wider multi-sited research project (2014-2018) which started at migrants' places of origin (Thailand). The second author followed the migration trajectories (Marcus, 1995) of Thai workers to Singapore, where they were working under the Work Permit or $\mathrm{S}$-Pass scheme. Altogether, 51 semi-structured interviews were conducted, combined with participatory observation. Additionally, five photo-interviews were conducted, during which photos taken by a former migrant worker to Singapore were shown to the participants as an elicitation method, to talk about the changes in the migration system and working conditions. In addition to this, the author conducted eight mappings of migration pathways between Thailand and Singapore, and joined two of the monthly dormitory visits with the Royal Thai Embassy in Singapore.

The research with migrant professionals, conducted by the first author (2013-2017), is part of a larger project that looked into the relationship between mobilities, encounters, and the role of digital media in migrants' perceptions of Singapore. It included 50 professionals of different origins and transnational backgrounds, staying on Employment Passes or with permanent residence. Migrant professionals are defined as migrant subjects who are highly skilled-with a tertiary-level education degree, or specialists working in high-level positions (cf. Föbker, Imani, Nipper, Otto, \& Pfaffenbach, 2016)whose qualifications and skills are recognized and who were working or looking for work in Singapore (Meier, 2016). The project combined narrative, in-depth, structured, and repertory-grid interviewing techniques with cognitive mapping and mobile media elicitation.

\section{An Empirical Comparison: Pathways to and through the Transient City Singapore}

\subsection{Arriving}

Migrant workers were flown in with low-cost airlines, picked up by the companies at the airport, and had to 
start working from day one. In contrast, the professionals usually arrived individually, were not picked up by employers at the airport, and thus performed their arrival and initial navigation through the city independently. Those professionals who had known people in Singapore before arriving often met their acquaintances soon after arriving. Hence, the imprint such contacts had made on their subsequent locational and social arrival was usually very large. Companies usually organized or supported the bureaucracy of finding a place to stay, applying for an Employment Pass, enrolling children for school, etc., for those who were posted. Some received 'orientation programmes,' during which they were shown apartments, the office, and, where applicable, education institutions for children. These interviewees' first impressions were much more streamlined and less affected by unexpected developments: "Because, the first three days I had immediately an orientation program somehow, I was chased around the city and I asked everyone only for apartments" (Lena, 27). The utilization of new digital media (such as navigation, restaurant, food or event apps), partly recommended by new acquaintances, or discovered through online search, co-produced and channeled the discovery of the city.

The arrival for most Thai migrant workers meant their first confrontation with a very new and unfamiliar context. Almost all Thai workers were torn between fascination at how "developed" and "clean" Singapore was and feelings of alienation and homesickness. Lek (50), a construction worker, for example observed a very different sense of community when he arrived. "My impression [was]...they open the door in a blink, they close the door and go to work in the evening, they come back, get in the room and close the door... [they] didn't know their neighbors" which is in great contrast to his life in a rural village in Thailand, where everybody knows everybody. The limited possibilities for mingling with locals was regrettably noted by some.

\subsection{Settling}

Right after arriving in Singapore migrants settle down and start to work. This process is institutionally regulated and has various spatial and social implications. For migrant workers the process of settling down is predetermined by the system of migration management. Those who come on a Work Permit have to stay in dormitories (see Figure 1) or, as they call them, "camps." Bunmee (51), who was working as a welder for over 17 years, described their situation as follows: "It is like sleeping in boxes...people who go to Singapore have been trained like soldiers...it is totally different from our country; you cannot sleep at the time you want to, you cannot eat at the time you want to." In the past the foreign workers were housed in makeshift container camps-often provided and improvised by their employers on or near the work site. Today, they have to be accommodated in high-tech dormitories such as the Tuas
View Dormitory or Kranji Lodge 1 which are run by profitoriented private operators and host up to 17,000 workers. The coming and going of the workers is registered by fingerprint and iris scanners and it is often not allowed to bring friends for visits. There are shops, gyms, laundries, canteens, internet rooms, and even cinemas and sports facilities to keep the workers as much as possible within the compounds.

This segregation logic continues within the dormitories. Here the workers are separated by nationality, which is quickly internalized by the workers: "Well the cooking was different, the food that we had, so we separated ourselves and also were sleeping separately. The employer understands that Thais and Bangladeshis are different in many ways, but we can work together" explained Lek. Hence, social encounters of (Thai) migrant workers are largely limited to co-nationals. Since most of the dormitories are located at the edge of the city, migrant workers are locationally separated from the host society. Hence, the possibilities of quotidian encounters other than with migrant workers are rare, and further hampered by language barriers.

Other than the migrant workers, migrant professionals are free to choose their accommodation on the private housing market. An initial and interim arrival phase to a hotel or hostel was followed by a relocation into rented accommodation. Although migrants remembered these spaces of initial arrival, in their stories they often appeared as somewhat detached, separate islands from their later everyday spaces of life in the city. Afterwards, the informants mostly moved to rented accommodation on the private housing market-the only housing formally available to temporary residents. The private housing market is separated from Singapore's highly successful social housing market (HDBs), which accommodates $81 \%$ of the Singaporean resident population (as of 2018 according to the Housing Development Board, 2019). Rental prices on the private market are high (in average $\$ 1,935$, making Singapore the 10th most expensive place for renting worldwide; CBRE, 2019). Nonetheless, and also due to more recent urban planning guidelines, which, e.g., develop mixed HDBs and private housing estates, migrant professionals are spatially embedded in the socio-spatial fabric of the city. Although this does not eliminate the emerging of housing areas preferred by expatriates, it prevents a much stronger segregation.

Despite popular narratives that attribute free choice of housing to professionals, depending on contract statuses, income, and special economic benefits, our informants were positioned quite differently on the housing market, and as a result also spatially in the city. Those who came on an expatriate contract and received housing allowances were indeed privileged and had a relatively free choice. So-called 'middling' professionals (Bork-Hüffer, 2017; Conradson \& Latham, 2005) on local contracts with salaries near the Employment Pass minimum (cf. Figure 1) had to look for more remote, cheaper 
and often shared housing. Parents in this group were not able to afford tuition fees or housing large enough to bring their families to Singapore.

\subsection{Mingling Locally and Connecting Elsewhere}

Although entitled to one day off per week, most of the migrant workers chose to work overtime to make their stay economically viable. On average our informants had one day off per month. In the remaining time, their lives were confined to their places of work and the dormitories. The mobility between these places is organized by the employer in trucks, and separated from the city's public transport. On work days there are hardly opportunities even for fleeting encounters with people other than co-workers and room-mates. In addition, as is further detailed in the next section, the employment situation is characterized by protracted temporariness and planning insecurity. Combined, this resulted in social practices which were almost entirely focused on workers' places of origin. During their rare free time they called relatives back home (usually through video-calls), spent time with fellow Thai workers, and only in rare cases engaged with Singaporeans. Those who had arrived before the mid-2010s, had often invested in buying a smartphone after coming to Singapore upon the pressure to keep in touch with their families, whereas those arriving later already owned one. A few workers had received business phones from their employers. One informant reported how his boss controlled his progress of work by requiring him to send pictures of the results regularly via his business phone.

The workers' translocal social embeddedness also found its material expression in the urban fabric of Singapore, in the Golden Mile Complex. It is a shopping mall in downtown Singapore which has been adopted by Thai migrant workers and has become their main social meeting point at weekends. It provides a range of services and shops catering to the needs of Thai workers including remittance services, a Thai supermarket, restaurants, Karaoke Bars with Thai waitresses, job placement agents, and a branch of the office of labor affairs of the Royal Thai Embassy. In the latter the workers can seek help regarding labor rights and employment issues, and also extend their Thai ID cards or continue educational qualifications via distance learning.

In contrast to the workers, the degree with which the professionals nourished their translocal contacts varied greatly. Decisive differences were related to their length of stay in the city, and particularly the location of their children: those who had not brought these along commonly spent a significant time daily using online social media communicating with their children. Further, professionals had shorter work hours, most (but not all) two days off per week, and as noted above were (relatively) free to reside in and move through the city. Quite differently from the socio-spatially segregated lives of migrant workers, their living and work contexts brought them in contact with diverse people. Overall, they had many more opportunities for fleeting encounters, as well as for establishing enduring sociability.

A feeling of 'having arrived' was for many professionals tied to the successful establishment of a local social network, underlining the importance attributed to socializing. Adopting new digital devices (particularly smartphones) and types of media (particularly WhatsApp and QQ) in order to adapt to new Singaporean or other migrant peers, played a significant role for connecting locally, but also for venturing through platforms (e.g., Online Citizen) to pick up socio-political debates otherwise disclosed to newcomers. For some, having a network of friends from various origins was important for identifying and belonging to a cosmopolitan elite. Others built up relations mostly to other professionals from their home countries. Reasons for this included a strong reliance on translocal networks through contacts to fellow migrants from their home countries before coming and joining their communities after arrival. Furthermore, particularly migrant parents' sociability was channeled through their children's (mostly international) schools. For others, a feeling of exclusion and discrimination or of cultural distance from local society was intertwined with not actively seeking to establish contacts with locals. This affected migrants from various origins, but interestingly, migrants from within Asia were most surprised that Singapore was culturally different from what they had expected, such as for Crisanto: "I was mentioning that, maybe as Asians going into another Asian country it's going to be more, how should I say?...Accepting." Class was a major-although not verbalized-factor driving the choice of relations, as almost none had established relations with non-tertiary-educated locals or migrants. Not being successful with establishing social relations, conversely, was often linked to plans or desires to return or move elsewhere.

Other than for migrant workers, meeting places of the professionals with their friends and acquaintances were scattered throughout the city as there was no perceived limitation of their movements in the city. Furthermore, the huge differences in income affected opportunities for participating in leisure activities: The Thai workers sent the money they earned almost entirely to Thailand. Not only did far fewer of the professionals remit money; having much higher incomes enabled many to participate in the expensive leisure life in Singapore, although this was clearly limited for 'middling professionals.'

\subsection{Planning Ahead}

Migrant workers (below S-Pass level) can only get work contracts for a maximum of two years and have to return immediately to their home countries after each contract period, then returning later for another contract. On average, our Thai informants stayed, with multiple short-term contracts, for a total of 10 to 15 years. 
However, the length of this protracted temporary stay was subject to their employers. Likewise, professionals on Employment Passes are allowed to reside in the city only as long as they are in active employment; any periods of unemployment or retirement would lead to immediate expulsion from the country. Similarly, to Work Permits, Employment Passes need to be renewed on a regular basis (usually every 2 years). Then again, migrant workers are deprived of the right to apply for long-term stay. Their only paths to a long-term future in Singapore would be marrying a Singaporean or a permanent resident. And they face an age limit which is not applicable to professionals: At the age of 60 all workers lose their Work Permit and have to return to their home countries within seven days. In contrast, some of the professionals we interviewed had applied for permanent residency or citizenship. Yet, given recent 'Singaporean First' measures, their chances had plummeted and the applications of some had been turned down (cf. Bork-Hüffer, 2017). Still, staying on an Employment Pass does not allow retirement in Singapore, even for professionals. Beyond these limitations, none of the professionals in this study considered Singapore as their anticipated place of retirement, mostly due to high costs of living.

Given these limits to the future stay of migrant workers, they live in a stage of 'permanent temporariness' (Swider, 2015; Yiftachel, 2009). However, they make their own decisions within these politics of mobility. Often, they align their decision to return back home with the educational stages of the children in Thailand. Sanan, a return migrant, is an example. He waited until his daughter obtained her university degree and his son finalized his teacher training before he returned back home. Despite the fact that Singaporean companies are often eager to hold onto experienced migrant workers, as soon as the latter no longer see the need to toil in Singapore, they leave, sometimes under the pretext that they only want to go home for a holiday. In particular, the younger generation of Thai workers is increasingly turning away from Singapore, as they see better conditions and more opportunities in other destinations such as South Korea, Taiwan, Israel or Sweden. As a result, the number of Thai migrant workers has dropped by over a third according to estimations by the Thai Royal Embassy (2014 to 2016 from 35,000 to about 20,000 to 15,000; Interview, 2016).

Among other reasons due to the fact that they can switch contracts while being in Singapore and apply for long-term stay, professionals' perspectives, though facing limitations, are nevertheless less constrained. There were roughly three groups when it came to future plans of stay or mobility: the first group planned to leave soon, especially due to better career or income opportunities elsewhere, the end of placements, and a lack of social connections. For 'middling' migrants high living costs, particularly resulting in the inability to bring their families or start a family in Singapore, were reasons to leave. Social reasons dominated among those who had plans or wishes to return to their native countries in the mid-term
( 5 to 10 , or occasionally up to 20 years' time). Planned return so as to reunite with their spouse and children, parents or friends was named by those who had left their spouse and/or children behind. Other reasons were the need to care for, or simply the desire to be close to aging family members. A third group of migrants that were mostly on permanent residence, usually with local partners and spouses, and were well-networked, planned to stay until retirement but not beyond.

\section{Discussion and Conclusions}

Our comparison of the two case studies has shown that there are fundamental differences in terms of the spatial emplacement of migrant workers and professionals in Singapore related to strict politics of mobilities and migration management, and as a result also in terms of their social incorporation into the host society.

This differential emplacement and treatment starts with the arrival in Singapore. The arrival of migrant workers is predefined by both the neoliberal state's endeavours to minimizing encounters by spatially segregating $\mathrm{mi}-$ grant workers in the 'camps,' and by company logics that are targeted at making imported labour productive from day one. It also imposes an engineered structure of everyday (im-)mobilities on the workers from the start, largely confining them to (moorings in) their places of labour, and dormitory compounds respectively. Similarly, their mobility between these places is controlled and manged by the employers through transport services. In contrast, professionals usually arrive individually, directly venturing into the city-state's 'throwntogetherness.' Recent research has underlined the relevancy of these mundane, short and 'fleeting encounters' in the context of superdiversity and politics of difference (Ye, 2016). Nonetheless, despite more freedom of choice and movement for professionals, the arrival of those posted by companies is partly steered through orientation programs and other support services, also targeted at ensuring they are ready to start working as soon as possible.

With regard to the process of settling, the notion of a neighbourhood or particular spaces of arrival and their role for emotionally and socially arriving does not hold true in the case of professionals. Their spaces of initial arrival (usually hotels or hostels) have little effect on or relation to their later lives in the city; they are anything but spaces of social arrival and remain rather disembedded 'islands' in the migrants' memories. Then again, their eventual spaces to stay are scattered throughout the city, very much defined by their incomes. Similarly, their social networks were not tied in particular to their spaces of stay. Overall, the spaces they became embedded in had little in common with Saunders' (2011) notion of arrival neighbourhoods. Singapore's tight urban planning and housing policies have also played a role here, as they prevented the emergence of segregated expatriate enclaves, which characterize other cities such as Bangkok or Kuala Lumpur. 
Very much in contrast, a segregation logic steers the state's separation of the migrant workers into dormitory compounds. This segregation is reflected in varioussometimes subtle-policies such as accommodation regulations, locational decisions on where dormitories are allowed to be build (often at the edge of the city-state in areas otherwise confined to industrial use) or regulations on free working days and overtime which reduce the time in which foreign workers could mingle with Singaporeans. Furthermore, within these dormitories, on the micro-scale, another segregation-logic is (re-)produced through the migrant workers' allocation to dormitory rooms and sections according to their nationality. This separation by nationalities is implemented by the private operators to 'avoid social conflicts.' This is, however, just a replication of the governments rhetoric that has always stressed the necessity of strictly managing and differentiating the country's multicultural populace in order to avoid the repetition of ethnic clashes that occurred in the country in the 1960s (cf. Chua, 2003). This rhetoric is once more reproduced and legitimated through migrant workers' narratives of social and cultural differences between the workers. Consequently, encounters and sociability are minimised, not only with the local population but even between the migrants. At first sight, one could describe the new high-tech dormitories as arrival spaces in the sense of arrival infrastructures (Meeus et al., 2019). Yet, they deviate significantly from Saunders' (2011) notion of multi-layered and hybrid arrival places as they are gated fragments of the city only for migrant workers but not for locals.

Against the backdrop of other contributions, which suggest that 'arrival' implies achieving social embeddedness and 'integration' and even social upward mobility (cf. Meeus et al., 2019), the case of Singapore shows that this is not given, and that 'arrival' in the sense of social integration can be deliberately prevented-even over long periods of time. Migrant workers' local mingling was strongly differentiated by race and gender as it focused on their male co-workers and dormitory mates of their own nationality. Furthermore, through their translocal digital social practices, they maintained a strong sense of belonging with their places of origin, which again counteracted relating and bonding to Singapore (see also Peth \& Sakdapolrak, 2019; Peth et al., 2018). The combination of their socio-spatial segregation, permanent temporariness (Yiftachel, 2009), the structural manifestation of the translocal space of the Golden Mile, and the translocal connectedness to their places of origin resulted in hardly any enduring social relations to Singaporeans, even after staying more than a decade. In such a way, as Ye (2017) argued, migrant workers' inclusion remains limited to civility in everyday encounters, whereas building enduring sociability or intimacy is deliberately prevented, also through laws forbidding marriages and childbirth by migrant workers. Yet migrant workers also move within the city, and their trajectories cannot be merely reduced to the state-defined migrant spaces such as the dormitories as is manifested, e.g., in the vibrant translocal space of the Golden Mile.

In contrast, professionals had many more opportunities for venturing through the social fabric of the city and becoming socio-spatially embedded by building ties and bonding emotionally to the city. For many the feeling of (not) having arrived and the entailed feeling of (not) belonging and being attached to the city-state were very much tied to having (not) managed to build up a local social network. Particularly 'middling professionals,' who do not have enough money to finance the stay of their children, were translocally embedded abroad, due to Singapore's migration management that benefits capital.

With regard to migrants' plans of stay or mobility, Singapore's strict politics of mobility affects the prospects of staying for all groups with temporary statuses, as their stay ends immediately with the ending of their work contracts. Yet whereas workers on Work Permits are deprived of the right of permanent stay or naturalization, professionals on Employment Passes may apply for both, and some of our participants had applied for permanent residence or citizenship. However, the 'Singaporeans First' policies (cf. Section 3) have further emphasized temporary perspectives for professionals too. Moreover, independent of the immigration legislation, costs of living made all professionals want to leave the city-state latest at retirement. Overall, this makes the concept of 'arrival city' unsuitable for capturing the mostly temporary realities of stay for both groups, as even though many workers and professionals in Singapore stay for a significant time span, up to decades, they plan to leave eventually. Still, perceived temporality is relative and for workers a feeling of 'permanent termporariness' is clearly more pronounced through their lack of opportunities for socially and emotionally bonding locally.

We argue that the concept of transient spaces more adequately captures the socio-spatial and -technological embedding of workers and professionals. For both groups, the concept captures how migrants are embedded in a 'farrago of overlapping' social, material and (we add) technological spaces "deriving from and simultaneously being shaped by (power) relations" (Bork-Hüffer et al., 2016, p. 142) rather than spatially confined arrival spaces. Professionals' power positions mean their freedom regarding mobilities and encounters is much greater than that of workers, as a result of which their spaces of interaction, work, leisure, and socializing stretch across various locations in the city-state and beyond-virtually and offline. Still, these were coshaped by the availability, assemblages, and local practices of media and technology use and their affordances, as well as state orderings of the split public-private housing market, with public housing being largely inaccessible to foreigners in general, and dependent upon limited prospects of stay.

Workers' everyday offline local sociability, mobilities, and practices on work days, in turn, are greatly 
limited to interactions with male co-workers, foremen, and security personnel and locationally confined to the 'camps,' work sites, and the corridors in between. At the same time, through digital means they remained strongly translocally embedded in their places of origin. Overall, their everyday spaces are increasingly coshaped, surveilled and controlled by socio-technological orderings. These range from fingerprint and iris scanners that regulate their entry and exit to the 'camps' (at the time of writing in May 2020, during the COVID-19 pandemic, further mechanisms were established to constrain workers' movements to sections of the dormitories), wide-spread CCTV on work sites and within the camps, distance control through business phones to the affordances (time, financial) of the mobile media they employ for connecting to peers abroad. Altogether, these orderings have fostered what Elwood $(2020$, p. 1) referred to as "adverse incorporation."

Simultaneously, whereas professionals started adopting different media in a strive to stay informed, discover the city or adapt and connect to peers in Singapore, workers remained embedded in the digital and social spaces they had been part of prior to migrating. Hereby, time barriers due to significantly longer work hours, language barriers, and more social obligations to translocally connect to families abroad limit not only workers' opportunities to venture through physical space and social 'throwntogetherness' in Singapore but also their digital opportunities to connect, become informed, and explore. This difference starkly reflects a digital reproduction of existing offline inequalities, largely co-produced by a differentiated management and politics towards the two groups.

It is important to note that the extent of statedriven politics of mobility and migrant management in Singapore that seek to maximize order and control over migrant bodies and subjectivities is exceptional. Its bifurcated migration management affects migrant workers through its clear-cut, state-engineered locational segregation and control over everyday mobilities most. Workers are wanted for their labour, which nourishes the country's construction and manufacturing sectors, but otherwise they are separated, not incorporated. Simultaneously, more concessions are made to the socalled 'foreign talents,' a strategy maintained since the 1980 s to sustain the city-state's status as a global city and model for economic and urban achievements. As we have argued, the state's and companies' neoliberal logics here go hand in hand, maximizing productivity of labour and-in the case of workers-minimizing any other enduring sociability, intimacy, or bonding. As we have further shown, looking at migration not as an end point (arrival) but prolonged pathway and process helps to bring to fore how the politics of mobility, migration management, and differential inclusion play out dynamically and differently throughout the migration process and relate to migrants' differential embedding in transient spaces.

\section{Acknowledgments}

We are grateful to the many migrants and their families who shared their stories and life experiences with us. We are also thankful to the anonymous reviewers for their valuable and constructive suggestions.

\section{Conflict of Interests}

The authors declare no conflict of interests.

\section{References}

Abu-Lughod, J. (1961). Migrant adjustment to city life: The Egyptian case. American Journal of Sociology, 67(1), 22-32. https://doi.org/10.1086/223047

Amin, A. (2013). Telescopic urbanism and the poor. City, 17(4), 476-492. https://doi.org/10.1080/13604813. 2013.812350

Bagelman, J. J. (2016). Sanctuary city: A suspended state. London: Palgrave Macmillan.

Beaverstock, J. V. (2011). Servicing British expatriate 'talent' in Singapore: Exploring ordinary transnationalism and the role of the 'expatriate' club. Journal of Ethnic and Migration Studies, 37(5), 709-728. https://doi.org/10.1080/1369183X.2011.559714

Bork-Hüffer, T. (2017). The mobility intentions of privileged and middling migrant professionals in Singapore: A cross-cultural comparison, and the effects of the "Singaporeans first" strategy. ASIEN, 143, 64-92.

Bork-Hüffer, T., Etzold, B., Gransow, B., Tomba, L., Sterly, H., Suda, K., . . . Flock, R. (2016). Agency and the making of transient urban spaces: Examples of migrants in the city in the Pearl River Delta, China, and Dhaka, Bangladesh. Population, Space and Place, 22(2), 128-145. https://doi.org/10.1002/psp.1890

CBRE. (2019). Global living 2019. London: CBRE. Retrieved from https://www.cbreresidential.com/uk/ sites/uk-residential/files/CBRE-Global\%20LivingArtwork-Phase\%206-v18.pdf

Chua, B. H. (2003). Multiculturalism in Singapore: An instrument of social control. Race \& Class, 44(3), 58-77. https://doi.org/10.1177/0306396803044003025

Conradson, D., \& Latham, A. (2005). Transnational urbanism: Attending to everyday practices and mobilities. Journal of Ethnic and Migration Studies, 31(2), 227-233. https://doi.org/10.1080/ 1369183042000339891

Conzen, K. N. (1979). Immigrants, immigrant neighborhoods, and ethnic identity: Historical issues. The Journal of American History, 66(3), 603-615. https://doi. org/10.2307/1890298

Cresswell, T. (2010). Towards a politics of mobility. Environment and Planning D: Society and Space, 28(1), 17-31. https://doi.org/10.1068/d11407

Datta, A. (2018). The digital turn in postcolonial urbanism: Smart citizenship in the making of India's 100 smart cities. Transactions of the Institute of 
British Geographers, 43(3), 405-419. https://doi.org/ 10.1111/tran.12225

Department of Statistics Singapore. (2019a). Population and population structure. Department of Statistics Singapore. Retrieved from https://www. singstat.gov.sg/find-data/search-by-

theme/population/population-and-population-

structure/latest-data

Department of Statistics Singapore. (2019b). Summary table: Labour force. Department of Statistics Singapore. Retrieved from https://stats.mom.gov.sg/ Pages/Labour-Force-Summary-Table.aspx

Elwood, S. (2020). Digital geographies, feminist relationality, Black and queer code studies: Thriving otherwise. Progress in Human Geography, 68(1), 1-20. https://doi.org/10.1177/0309132519899733

Föbker, S., Imani, D., Nipper, J., Otto, M., \& Pfaffenbach, C. (2016). Translocal life and integration of highly-skilled migrants in Germany. Erdkunde, 70(2), 109-124. https://doi.org/10.3112/erdkunde. 2016.02.01

Gabrys, J. (2014). Programming environments: Environmentality and citizen sensing in the smart city. Environment and Planning D: Society and Space, 32(1), 30-48. https://doi.org/10.1068/d16812

Glick Schiller, N., \& Çağlar, A. (2016). Displacement, emplacement and migrant newcomers: Rethinking urban sociabilities within multiscalar power. Identities, 23(1), 17-34. https://doi.org/10.1080/ 1070289X.2015.1016520

Gomes, C. (2017). Transient mobility and middle class identity. Singapore: Springer Singapore. https://doi. org/10.1007/978--981-10--1639-4

Hannam, K., Sheller, M., \& Urry, J. (2006). Editorial: Mobilities, immobilities and moorings. Mobilities, 1(1), 1-22. https://doi.org/10.1080/17450100500489189

Hiam, L., Steele, S., \& McKee, M. (2018). Creating a 'hostile environment for migrants': The British government's use of health service data to restrict immigration is a very bad idea. Health Economics, Policy, and Law, 13(2), 107-117. https://doi.org/10.1017/ S1744133117000251

Ho, E. L.-E. (2006). Negotiating belonging and perceptions of citizenship in a transnational world: Singapore, a cosmopolis? Social \& Cultural Geography, 7(3), 385-401. https://doi.org/10.1080/ 14649360600715086

Housing Development Board. (2019). Key statistics (HDB Annual Report 2018/2019). Singapore: Housing Development Board. Retrieved from https:// services2.hdb.gov.sg/ebook/AR2019-keystats/ $\mathrm{html} 5 /$ index.html?\&locale=DEU

Iwasaki, K. (2015). Singapore's strategies for attracting highly-skilled foreign human resources: How does Singapore recruit foreign talent? RIM Pacific Business and Industries, 15(56), 1-27.

Kitchin, R. (2017). Thinking critically about and researching algorithms. Information, Communication
\& Society, 20(1), 14-29. https://doi.org/10.1080/ 1369118X.2016.1154087

Koh, S. Y. (2015). Temporalities of citizenship: MalaysianChinese skilled migrants in Singapore and returnees to Malaysia. Asian and Pacific Migration Journal, 24(1), 3-27. https://doi.org/10.1177/ 0117196814565158

Logan, J. R. (2006). Variations in immigrant incorporation in the neighborhoods of Amsterdam. International Journal of Urban and Regional Research, 30(3), 485-509. https://doi.org/10.1111/ j.1468--2427.2006.00677.x

Marcus, G. E. (1995). Ethnography in/of the world system: The emergence of multi-sited ethnography. Annual Review of Anthropology, 24(1), 95-117. https:// doi.org/10.1146/annurev.an.24.100195.000523

Marcuse, P. (1996). Of walls and immigrant enclaves. In N. Carmon (Ed.), Migration, minorities and citizenship: Immigration and integration in post-industrial societies. Theoretical analysis and policy-related research (Vol. 6, pp. 30-45). Houndmills: Macmillan Press. https://doi.org/10.1007/978--1-349--249459_3

Massey, D. (1991). A global sense of place. Marxism Today, June, 24-29.

Massey, D. (2005). For space. London: SAGE.

Meeus, B., Arnaut, K., \& van Heur, B. (Eds.). (2019). Arrival infrastructures: Migration and urban social mobilities. New York, NY: Palgrave Macmillan.

Meier, L. (2016). Introduction: Local lives, work and social identities of migrant professionals in the city. In L. Meier (Ed.), Routledge advances in sociology (Vol. 130, pp. 1-17). London and New York, NY: Routledge.

Ministry of Manpower of Singapore. (2020). Work passes and permits. Ministry of Manpower. Retrieved from https://www.mom.gov.sg/passes-and-permits

Moore, C. (2015). Honiara: Arrival city and Pacific hybrid living space. The Journal of Pacific History, 50(4), 419-436. https://doi.org/10.1080/00223344. 2015.1110869

Nee, V., Sanders, J. M., \& Sernau, S. (1994). Job transitions in an immigrant metropolis: Ethnic boundaries and the mixed economy. American Sociological Review, 59(6), 849. https://doi.org/10.2307/2096372

Neuwirth, R. (2005). Shadow cities: A billion squatters, a new urban world. New York, NY: Routledge.

Ong, A. (2011). Introduction: Worlding cities, or the art of being global. In A. Roy \& A. Ong (Eds.), Worlding cities: Asian experiments and the art of being global (pp. 2-26). Oxford: Wiley-Blackwell.

Oswin, N., \& Yeoh, B. S. A. (2010). Introduction: Mobile city Singapore. Mobilities, 5(2), 167-175. https://doi. org/10.1080/17450101003665002

Papadopoulos, D., \& Tsianos, V. S. (2013). After citizenship: Autonomy of migration, organisational ontology and mobile commons. Citizenship Studies, 17(2), 178-196. https://doi.org/10.1080/13621025. 2013.780736 
Pécoud, A. (2013). Introduction: Disciplining the transnational mobility of people. In M. Geiger \& A. Pécoud (Eds.), Disciplining the transnational mobility of people (pp. 1-14). London: Palgrave Macmillan.

Peth, S. A., \& Sakdapolrak, P. (2019). When the origin becomes the destination: Lost remittances and social resilience of return labour migrants in Thailand. Area, 72, 1-11. https://doi.org/10.1111/area.12598

Peth, S. A., Sterly, H., \& Sakdapolrak, P. (2018). Between the village and the global city: The production and decay of translocal spaces of Thai migrant workers in Singapore. Mobilities, 13(4), 455-472. https://doi. org/10.1080/17450101.2018.1449785

Platt, M., Baey, G., Yeoh, B. S. A., Khoo, C. Y., \& Lam, T. (2017). Debt, precarity and gender: Male and female temporary labour migrants in Singapore. Journal of Ethnic and Migration Studies, 43(1), 119-136. https://doi.org/10.1080/1369183X.2016.1218756

Porst, L., \& Sakdapolrak, P. (2018). Advancing adaptation or producing precarity? The role of rural-urban migration and translocal embeddedness in navigating household resilience in Thailand. Geoforum, 97, 35-45. https://doi.org/10.1016/j.geoforum.2018.10. 011

Rose, G. (2017). Posthuman agency in the digitally mediated city: Exteriorization, individuation, reinvention. Annals of the American Association of Geographers, 107(4), 779-793. https://doi.org/10.1080/ 24694452.2016.1270195

Saunders, D. (2011). Arrival city: How the largest migration in history is reshaping our world. New York, NY: Pantheon Books.

Smith, M. P. (2005). Transnational urbanism revisited. Journal of Ethnic and Migration Studies, 31(2), 235-244. https://doi.org/10.1080/ 1369183042000339909

Solis, F. (1971). Socioeconomic and cultural conditions of migrant workers. Social Casework, 52(5), 308-315. https://doi.org/10.1177/104438947105200508

Steinbrink, M. (2009). Urbanisation, poverty and translocality: Insights from South Africa. African Population Studies, 23, 219-252.

Swider, S. (2015). Building China: Precarious employment among migrant construction workers. Work, Employment and Society, 29(1), 41-59. https://doi. org/10.1177/0950017014526631

Wilson, K. L., \& Portes, A. (1980). Immigrant enclaves: An analysis of the labor market experiences of Cubans in Miami. American Journal of Sociology, 86(2), 295-319. https://doi.org/10.1086/227240

Wong, D. (1997). Transience and settlement: Singapore's foreign labor policy. Asian and Pacific Migration Journal: APMJ, 6(2), 135-167. https://doi.org/10.1177/ 011719689700600201

Ye, J. (2016). The ambivalence of familiarity: Understanding breathable diversity through fleeting encounters in Singapore's Jurong West. Area, 48(1), 77-83. https://doi.org/10.1111/area.12237

Ye, J. (2017). Managing urban diversity through differential inclusion in Singapore. Environment and Planning D: Society and Space, 35(6), 1033-1052. https:// doi.org/10.1177/0263775817717988

Yeoh, B. S. A. (2006). Bifurcated labour: The unequal incorporation of transmigrants in Singapore. Tijdschrift Voor Economische En Sociale Geografie, 97(1), 26-37. https://doi.org/10.1111/j.1467--9663.2006.00493.x

Yeoh, B. S. A., \& Lam, T. (2016). Immigration and its (dis)contents. American Behavioral Scientist, 60(5/6), 637-658. https://doi.org/10.1177/ 0002764216632831

Yiftachel, O. (2009). Theoretical notes on 'Gray cities': The coming of urban apartheid? Planning Theory, 8(1), 88-100. https://doi.org/10.1177/ 1473095208099300

\section{About the Authors}

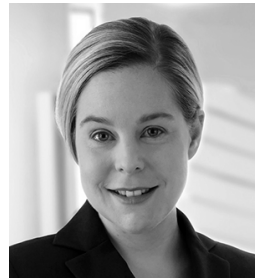

Tabea Bork-Hüffer is Professor for Human Geography at the Department of Geography, University of Innsbruck, Austria. Her research centers around the intersections of digitization, (im-)mobilities, and urbanization, with a regional focus on Southeast Asia, China, and Austria. Previously she was Alexandervon-Humboldt Foundation Fellow at the Migration Cluster, Asia Research Institute, National University of Singapore (NUS) and Post-Doc at the Department of Geography at University of Cologne, Germany.

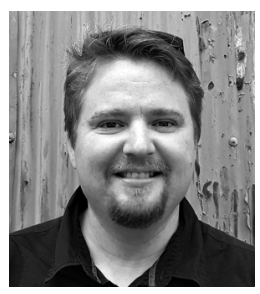

Simon Alexander Peth is a Human Geographer based at the Department of Geography, University of Innsbruck, Austria. He focuses on social geography in the Global South. Simon studied development geography, anthropology and development economics, at the University of Bonn, Germany, and has over 10 years research experience on development issues, climate change adaptation, human mobility and migration in Ethiopia, Bangladesh, Thailand, Singapore and Germany. 